\title{
Drivetrains on floating offshore wind turbines: lessons learned over the last 10 years
}

\author{
Amir R. Nejad' 1 (D) Jone Torsvik ${ }^{2}$ \\ Received: 30 November 2020 / Accepted: 5 March 2021 / Published online: 29 March 2021 \\ (c) The Author(s) 2021
}

\begin{abstract}
This paper presents lessons learned from own research studies and field experiments with drivetrains on floating wind turbines over the last ten years. Drivetrains on floating support structures are exposed to wave-induced motions in addition to wind loading and motions. This study investigates the drivetrain-floater interactions from two different viewpoints: how drivetrain impacts the sub-structure design; and how drivetrain responses and life are affected by the floater and support structure motion. The first one is linked to the drivetrain technology and layout, while the second question addresses the influence of the wave-induced motion. The results for both perspectives are presented and discussed. Notably, it is highlighted that the effect of wave induced motions may not be as significant as the wind loading on the drivetrain responses particularly in larger turbines. Given the limited experience with floating wind turbines, however, more research is needed. The main aim with this article is to synthesize and share own research findings on the subject in the period since 2009, the year that the first full-scale floating wind turbine, Hywind Demo, entered operation in Norway.
\end{abstract}

\section{Antriebsstränge in schwimmenden Offshore-Windkraftanlagen: Erkenntnisse der letzten 10 Jahres}

\section{Zusammenfassung}

In diesem Beitrag werden Erkenntnisse aus eigenen Forschungsarbeiten und Feldexperimenten mit Antriebssträngen in schwimmenden Windkraftanlagen der letzten zehn Jahre vorgestellt. Antriebsstränge auf schwimmenden Plattformen sind zusätzlich zu Windlasten und -bewegungen auch welleninduzierten Bewegungen ausgesetzt. Diese Studie untersucht die Wechselwirkungen zwischen Antriebsstrang und Plattform aus zwei verschiedenen Blickwinkeln: wie der Antriebsstrang die Konstruktion der Plattform beeinflusst; und wie sich die Bewegungsabläufe der Plattform auf die Dynamik und die Lebensdauer des Antriebsstrang auswirken. Die erste Frage bezieht sich auf die Antriebsstrangstechnik und -gestaltung, während die zweite Frage den Einfluss der welleninduzierten Bewegung betrifft. Die Ergebnisse für beide Perspektiven werden vorgestellt und diskutiert. Insbesondere wird hervorgehoben, dass bei größeren Windkraftanlagen der Einfluss der welleninduzierten Bewegungen auf die Dynamik des Antriebsstrangs nicht so signifikant ist wie die Windlasten. In Anbetracht der begrenzten Erfahrung mit schwimmenden Windkraftanlagen ist jedoch weitere Forschungsarbeit erforderlich. Das Hauptziel dieses Artikels ist es, eigene Forschungsergebnisse zu diesem Thema seit 2009, dem Jahr, in dem die erste schwimmende Windkraftanlage, Hywind Demo, in Norwegen in Betrieb genommen wurde, zusammenzufassen und zu teilen.

1 Marine Technology Department, Norwegian University of Science and Technology, 7491 Trondheim, Norway

2 Equinor ASA, Sandslivegen 90, 5254 Sandsli, Norway 


\section{Introduction}

An offshore wind turbine installation is the result of a twostage design process. The first stage is the design of a standardized Rotor-Nacelle Assembly (RNA) and possibly a standardized tower as an offering from the turbine manufacturer to the wind power developers. The second stage is the design of a foundation or substructure to suit the site conditions of a specific project. The Hywind demo by Equinor in 2009, the world's first floating wind turbine demonstrator, was fitted with a standard Siemens Wind Power (now SGRE) 2.3 MW onshore RNA.

Similarities naturally exist between the two stages of the design process, in terms of both general methodology and, notably for the wind power industry, the central role of global numerical analyses using the aeroelastic simulation tools. As wind turbines are highly fatigue-driven structures subject to stochastic environmental loads, numerous load cases need to be considered. The differences between the two stages lie in the aeroelastic model scope and input, and the design and verification of components and subsystems.

Design and verification of components and subsystems, such as the drivetrain, belong to the RNA development process. The overall RNA design, in practice synonymous with the "Danish concept"; a three-bladed, horizontal-axis upwind turbine adapted to a tubular tower, is established first. Then follows detail design, making more visible the nuances between the different suppliers. In this process, the aeroelastic simulations are used to generate the input to the mostly decoupled detailed-level analyses with purpose-matched model fidelity. The main bearings are in reality connecting the aeroelastic-level and drivetrain-level analyses - their characteristics being important in both domains [13].

As floating wind turbine development has progressed, with the first floating wind farm Hywind Scotland in operation since 2017, the question has been raised about the influence of floating sub-structures on the drivetrain. The motions of floating turbines subject the drivetrain to different dynamics than bottom-fixed and onshore turbines. However, there are currently no specific guidelines or standards for drivetrains on floating substructures. The interaction between floating substructures and wind turbine drivetrains can be viewed from two different perspectives:

(a) how the drivetrain influences the floating sub-structure design, and

(b) how the drivetrain is affected by the floating sub-structure.

The first question is related to the drivetrain design and technology since weight, size, geometry and configuration of the drivetrain influence the sub-structure design. The main aspects here are the tower-top weight and position of the center of gravity which are important parameters for the structural design, especially for floating turbines. In addition, the geometry and configuration of the drivetrain influ-
Fig. 1 Different bearing layouts. a Solid, torque-transferring shaft, b Hollow, torque-transferring shaft, c Inverted, multiple bearings on hollow, stationary shaft, d Inverted, single bearing on hollow, stationary shaft

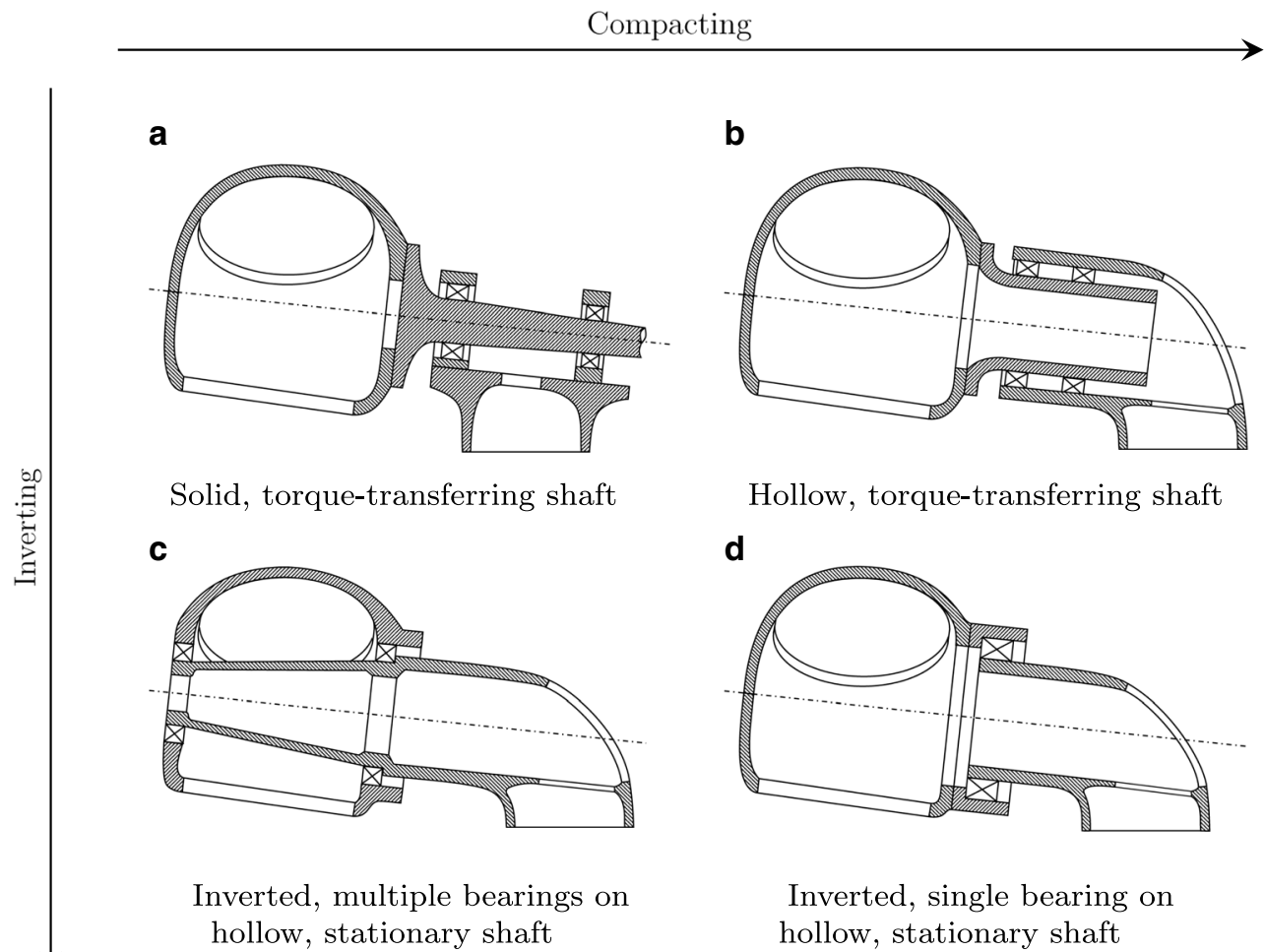

hollow, stationary shaft 
ence the bedplate and nacelle designs. The second question is related to how drivetrain is affected by the substructure and can be expressed in other words as: "do floating turbine motions and associated forces impact the drivetrain design?". In this paper "floater" and "floating substructure" mean the part of the structure providing buoyancy - for example spar or semi-submersible type structures. The term "support structure" includes both the tower and the substructure.

This paper presents a synthesis of the results of several own studies over last ten years addressing the above questions. For theoretical studies, the 5 and $10 \mathrm{MW}$ reference drivetrains have been employed for comparative studies, $[11,18]$. The field experiences from operation of the world's first floating farm have also been used in this study. The main aim of the paper is to contribute to better understanding of design requirements of drivetrains for floating turbines.

\section{Effects of drivetrain on floating support structure design}

The weight, size, configuration and layout of the drivetrain influence the support structure design. The most common types of drivetrains employed in the industry today are high speed, medium (hybrid) or direct drives which offer different weight, size and configuration. In the following sections, the impact of layout and generator configuration on the support structure is discussed.

\subsection{Impact of main bearing and drivetrain layout on support structure}

In addition to the drivetrain type, the configuration and layout of the drivetrain impacts the design of supporting structure. Fig. 1 presents the state of the art and trend of configurations employed today in the industry. There has

Table 1 State-of-the-art of drivetrain technologies in multimegawatt onshore and offshore wind turbines at a glance (up to 10 MW) [7]

Technology Layout

1. High-speed squirrel cage induction generator

- Merits: cheap, simple generator design

- Drawbacks: sensitive to transients, low efficiency

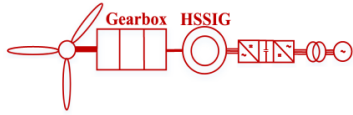

2. High-speed doubly fed induction generator

- Merits: cheap, fractional converter

- Drawbacks: sensitive to transients, low efficiency

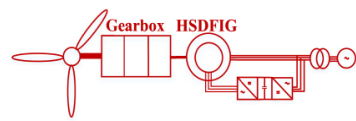

3. Direct-drive wound rotor synchronous generator

- Merits: cheap

- Drawbacks: brushes, low efficiency, higher weight

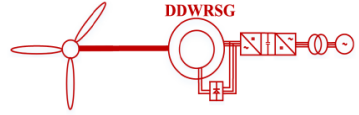

4. Medium-speed wound rotor synchronous generator

- Merits: cheap

- Drawbacks: brushes, low efficiency

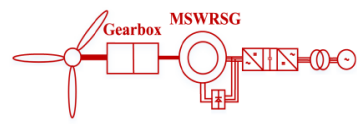

5. Direct-drive permanent-magnet synchronous generator

- Merits: low maintenance, high efficiency

- Drawbacks: expensive

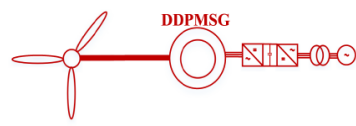

6. Medium-speed permanent-magnet synchronous generator

- Merits: low maintenance, high efficiency, less weight for higher powers

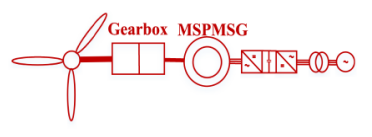




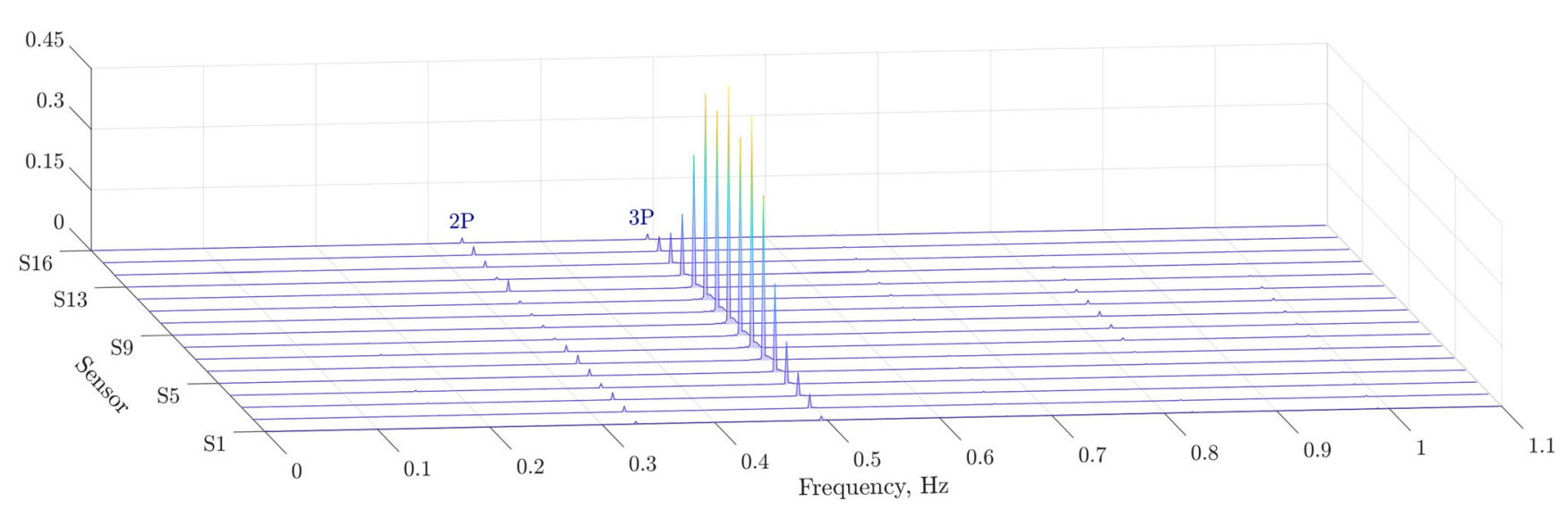

Fig. 2 Bending strain low-frequency spectra across sensor positions [15]

been a trend towards compacting the drivetrain, in some cases by merging the hub and main shaft and also inverting the main bearings - or even using a single main bearing.

Fig. 1a shows a traditional arrangement, featuring an essentially solid shaft supported by two separately housed bearings attached to a bedplate. The large, overhung, dynamically loaded rotor in combination with the relatively slender shaft commonly inspired the use of a spherical bearing in the forward position to avoid edge loading. As is well known, however, shaft deflections potentially introduce non-torque loads to be dealt with at the rear end where either a gearbox or a generator is attached. Examples of evolutionary design changes to accommodate the deflections included going from a three-point suspension to a fourpoint suspension with a cantilevered gearbox and resilient torque reaction mounts. Unless integrated into a larger part of the drivetrain or turbine structure, the gearbox will have two torque reaction supports for symmetry of loads [14].

Modern pitch-controlled wind turbines are essentially shell structures in which the hollow root sections of the composite blades are directly attached to the hub via slewing bearings. The flexibility of pitch bearings has been investigated by Chen et al. [2], Plaza et al. [12] and others.
The idea that a single bearing could support the hub and function as a main bearing was exploited in early designs such as the Lagerwey turbines and the Zephyros Z72 turbine $[3,16]$. A single-bearing layout is illustrated in Fig. 1d, although in an inverted bearing configuration.

The drivetrain layouts proposed by the INNWIND project largely resemble those shown in Fig. 1b and c. Although featuring two separate main bearings, they strongly suggest that one way to achieve compact and lightweight designs for large wind turbines is to incorporate the torquetransferring and the supporting elements of the drivetrain as extensions of the shell-like hub and tower-a concept further exploited in NREL's and DTU's 15 MW reference model description. Leveraging the capacity of rolling element bearing for being made with large diameters and thin sections is rather fundamental to arrive at these hollow structures. One benefit of this approach is high torsional stiffness.

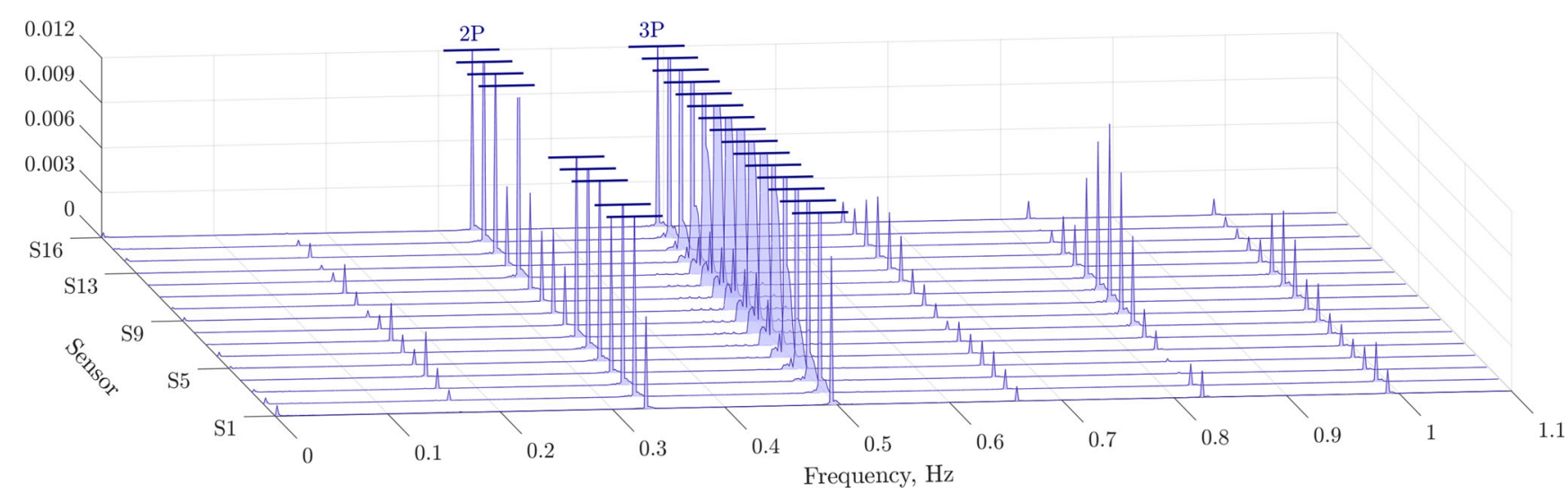

Fig. 3 Bending strain low-frequency spectra across sensor positions, zoomed in on magnitude [15] 
Table 2 Environmental conditions

\begin{tabular}{|c|c|c|c|c|c|c|c|c|c|c|}
\hline$\overline{\mathrm{EC}}$ & 3 & 8 & 17 & 21 & 34 & 66 & 71 & 80 & 81 & 84 \\
\hline$U_{w}\left(\mathrm{~ms}^{-1}\right)$ & 6 & 11 & 20 & 24 & 16 & 6 & 11 & 20 & 21 & 24 \\
\hline$H_{S}(\mathrm{~m})$ & 1.7 & 2.3 & 4.3 & 5.4 & 4.9 & 3.1 & 3.8 & 6 & 6.3 & 7.2 \\
\hline$T_{p}(\mathrm{~s})$ & 9.5 & 10 & 11.3 & 11.9 & 11.7 & 9.2 & 9.7 & 11 & 11.1 & 11.6 \\
\hline
\end{tabular}

\subsection{Impact of generator technology on support structure design}

The technology used today in the world's first commercially operated floating wind farm, Hywind Scotland, is a direct drive drivetrain with a rated power of $6 \mathrm{MW}$. In the Hywind Tampen project currently under construction, $8 \mathrm{MW}$ direct drive turbines will be employed. Moghadam and Nejad [7] employed optimized analytical 10-MW drivetrain designs, representing the three most common, different drivetrain concepts, and compared the cost, efficiency, operation and dynamic behavior in a life-cycle perspective, using a systems engineering approach and considering both gearbox and generator effects. The results were in the favor of medium speed drivetrains indicating that utilization of gearbox can improve both the economics and operations of the wind turbine in 10-MW floating offshore wind turbines. Table 1 presents the most common generator types used in offshore wind turbines with the pros and cons in terms of investment and operational cost.

In terms of the weight, the generator choice very much depends on the choice of the layout and main bearing configuration as discussed in earlier Sect. 2.1.

\section{Effect of floating support structure on drivetrain responses}

The second question highlighted in Section 1 is how the drivetrain is affected by the sub-structure. The influence of floating support structure on the drivetrain dynamic responses can be seen in terms of the effect of floater motion, the tower top acceleration, the bedplate flexibility, and the turbine and farm level control strategies.

\subsection{Effect of floater motion on drivetrain responses}

In the study by Xing et al. [19], higher load variation was observed on a $750 \mathrm{~kW}$ drivetrain supported on a spar type floating wind turbine compared with a bottom-fixed support. Nejad et al. [8, 9] conducted a comparative fatigue damage study for a spar, two different semi-submersibles (with and without active ballast) and a tension leg platform (TLP) versus a bottom fixed support structure, considering bearing and gear damage accumulation in a $5 \mathrm{MW}$ reference gearbox [11], designed for the NREL 5 MW turbine [4].
The results indicated that the downwind main bearing in four points configuration which carries thrust force could experience higher damage for the floater with larger waveinduced motion, for example spar. However, other bearings and gears inside the gearbox, surprisingly, found to be not affected by the floater motions or even some of them with lower damage than the land-based ones, enjoying to be on a floater!

It was later found that this conclusion cannot be generalized for larger turbines with different layouts and configurations. The first-tier analysis of experimental data from a main bearing in a $6 \mathrm{MW}$ turbine on a spar-type floating substructure was conducted by Torsvik et al. [15] where measurements on main bearing were investigated.

Fig. 2 shows low-frequency spectra of the bending strain in 16 sensor positions installed on inner ring of the main bearing [15]. The spectra are based on the representative time series from operation around rated wind speed. It illustrates that 3P (P stands for blade passing frequency or rotational speed frequency) vibrations are totally dominant with the largest magnitudes localized in the lower half of the bearing. Barely visible in the same plot are peaks at $2 \mathrm{P}$ and $5 \mathrm{P}$.

Fig. 3 is the Fig. 2 zoomed in on the magnitude. Horizontal crossbars indicate curve clipping. Here, small peaks emerge also at $1 \mathrm{P}, 4 \mathrm{P}$ and $6 \mathrm{P}$. Thus, all peaks appear to align with the excitation frequencies $1 \mathrm{P}$ and $3 \mathrm{P}$ and combinations or multiples thereof. $3 \mathrm{P}$ is inherent in the design. $1 \mathrm{P}$ is physical, as only a perfect rotor would be free of imbalance forces, and that is hardly achievable. Whereas the $3 \mathrm{P}$ vibration shows a clear first-order magnitude distribution over the positions, the $2 \mathrm{P}$ and $5 \mathrm{P}$ peaks show opposing, singly symmetric second-order distributions.

Our experimental analysis shows that bending deflection occurs in the main bearings, largely driven by differential bending moments between the blades at $3 \mathrm{P}$ frequency, particularly from the tower shadow, and thus dependent on thrust. The effects of floater motion on bearing bending deflections are overshadowed by the effects of wind-induced loads. On the much smaller extensional deflections, the effects of floater motion are more the same order of magnitude as the wind-induced loads. This is an important result for future designs, as it indicates that the effects of floating operation on the mechanical components of the drivetrain overall are moderate compared to generic, wind-induced effects. 


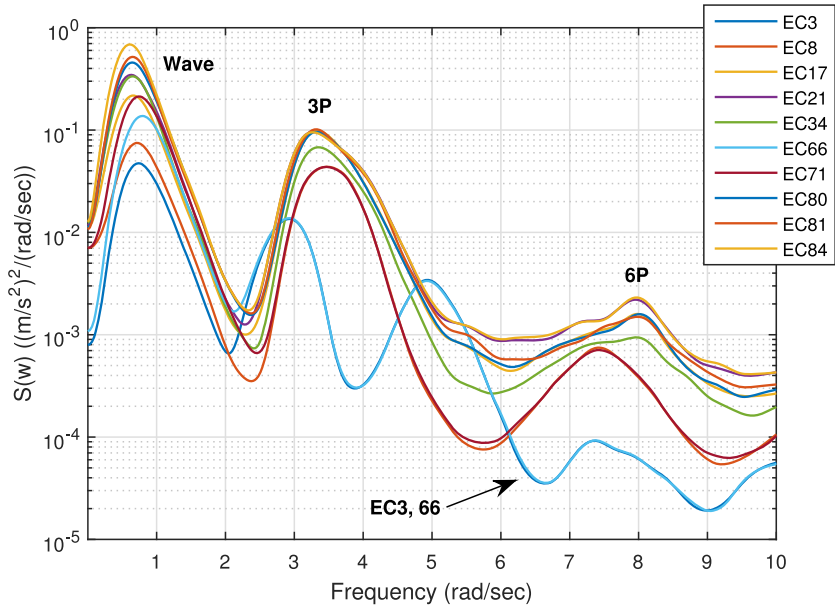

Fig. 4 Power spectrum of axial acceleration in different environmental conditions [10]

\subsection{Effect of tower top acceleration}

Common industrial practice for designing floating wind turbines is to set an operational limit for the tower-top axial acceleration, normally in the range of $0.2-0.3 \mathrm{~g}$, which is typically understood to be related to the safety of turbine components.

In a study by Nejad et al. [10] a series of environmental conditions as shown in Table 2 were used for the analysis of the maximum axial acceleration and its effect on the drivetrain damage in a $5 \mathrm{MW}$ spar type floating wind turbine.

As illustrated in Fig. 4, the wave-induced motion has the biggest contribution to the axial acceleration, followed by the tower shadow and turbulence effects at the 3P frequency.

Although the maximum acceleration provides a good indication of the wave-induced loads, it is not seen to be a good predictor for significant fatigue damage on the drivetrain components, for example the main bearings [10]. Fig. 5 shows the equivalent fatigue load versus the maximum axial acceleration for two main bearings in different load cases.

As it is shown in this Fig. 5, there are other environmental conditions with lower axial acceleration - specially those around rated wind speed - which reduce the fatigue life of the main bearings more than those with high axial accelerations. In the study by Nejad et al. [10] it was also found that the contribution of wind-induced thrust and tower shadow can be larger than the wave-induced motion, and this can be more significant for larger turbines, meaning that the wind induced excitation can be a design driver for drivetrain components rather than wave induced ones in large floating wind turbines.

In addition, from the global responses, the correlation between torque and axial force on the rotor and the maximum axial acceleration was investigated. It was found that the

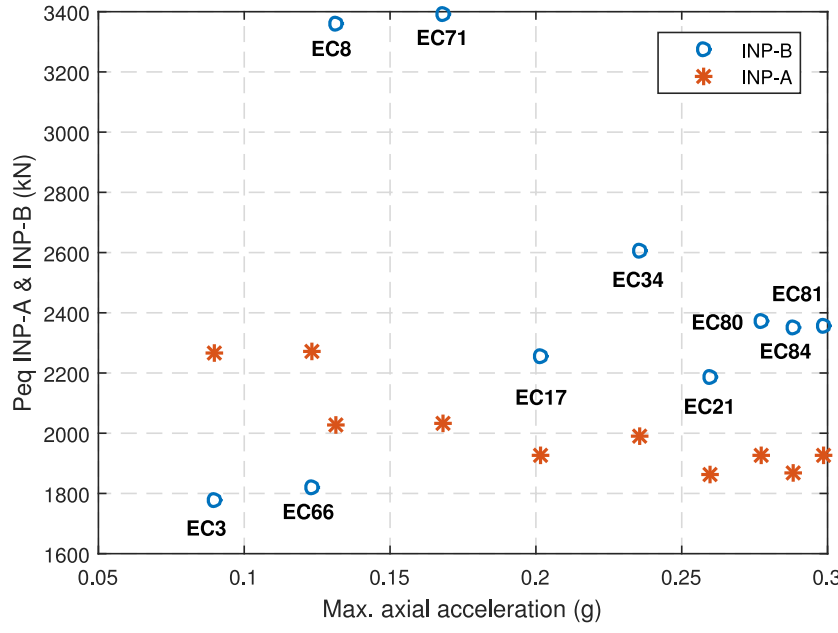

Fig. 5 Main bearings (INP-A upwind \& INP-B downwind bearing) equivalent fatigue load versus maximum axial acceleration [10]

torque and axial force are mainly affected by the pitch control system, and are not correlated with the maximum axial acceleration. Therefore, with respect to the main bearings, it was found that limiting the maximum axial acceleration may not be an efficient measure to make any conclusion about their maximum loading or fatigue life.

\subsection{Effect of rigid and flexible support on drivetrain responses}

The bedplate design impacts the drivetrain dynamics and consequently the fatigue damage of gears and bearings. A rigid bedplate model is faster in terms of dynamic response analysis while a flexible model increases the computational time and complexity of the model. In a study by Wang et al. [17] sensitivity of the drivetrain fatigue damage to varying fidelity in the bedplate modeling was studied. A 10MW medium speed drivetrain [18] installed on a spar type floating wind turbine was used in this study. The results - as shown in Fig. 6 indicate that the bedplate flexibility may increase the responses on bearings inside the gearbox, while may reduce the load effects on the main bearings [17]. This indicates also the effect of support structure design in terms of flexible versus rigid support on the life of the drivetrain components.

\subsection{Effect of turbine and farm control on drivetrain load effects}

It is also important to highlight that the control strategy, both at turbine and farm level, influences the drivetrain life. In a study by Lee et al. [6], three control modifications, active damping $(\mathrm{AD})$, energy shaping control without individual blade pitch (ES w/o IPC), and energy shaping control with individual blade pitch (ES w/IPC) were employed for 
Fig. 6 Comparison of load duration distribution and equivalent fatigue load (EFL) of the rigid and the flexible bedplate models of bearings in a $10 \mathrm{MW}$ spar type floating wind turbine at $10 \mathrm{~m} / \mathrm{s}$ wind speed, and wave height and period of $2.5 \mathrm{~m}$ and 10.1 sec., respectively [17]. a Main bearing upwind, $\mathbf{b}$ Planet carrier bearing, 1st stage
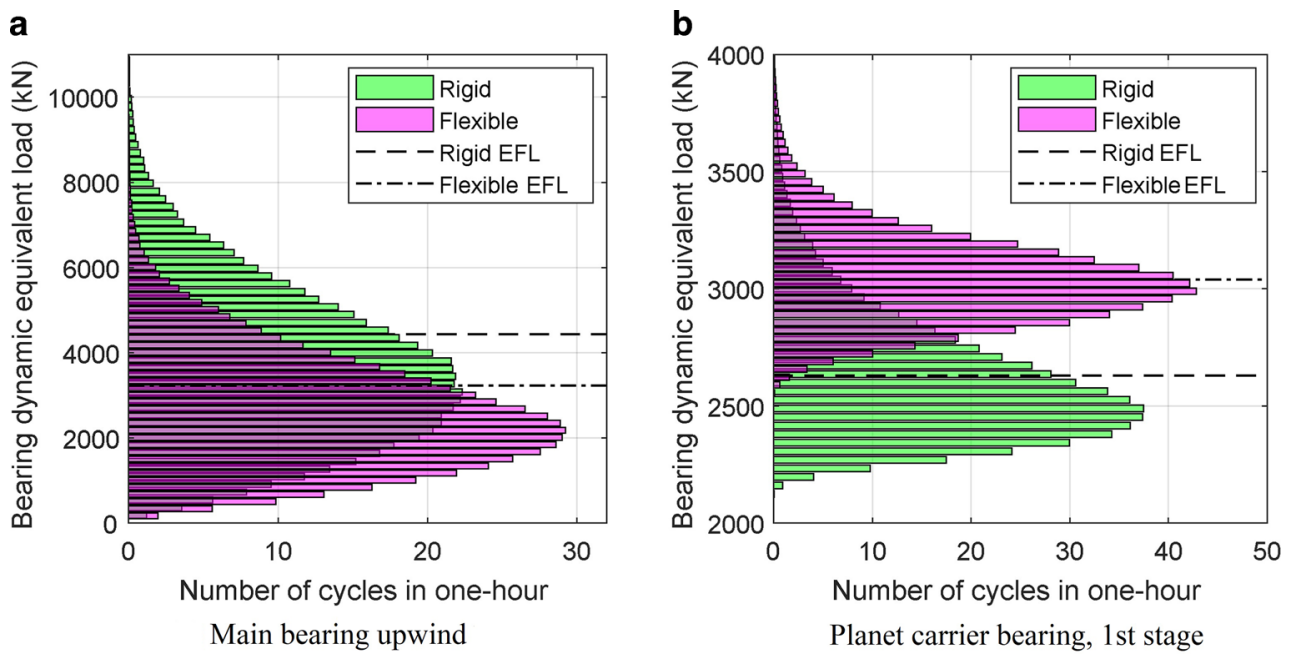

a $5 \mathrm{MW}$ spar type floating wind turbine [10]. The results - Figs. 7 and 8 - show increase of damage for the main bearing at rated and above rated environmental conditions for certain control strategy.

For farm level control, the recent study by Van Binsbergen et al. [1] indicates the importance of balance between power production strategy and drivetrain components life. Two 10 MW floating wind turbines were modeled in FASTFarm [5] and simulations were carried out by implementing two different farm control strategies: induction and wake steering control. The global results, obtained from FASTFarm, were then applied on local multi-body model of drivetrain to calculate the local responses. It was found that effects of the induction and wake steering control on mean values of drivetrain responses are generally identical with that of the global load responses. The increase of blade pitch angle would lower the standard deviations of drivetrain dynamic response of the wind turbine in upstream, while it affects very little the standard deviation response in the downstream turbine. As a contrast, wake steering control does not have large effect on drivetrain standard deviation response of the upstream turbine, while the increase of yaw angle would lead to the increase of the drivetrain standard deviation response of the downstream turbine. Main bearings and high speed bearings were found to be those which are the most effected, especially for the turbine in wake [1].

\section{Conclusions}

In this paper, the effects of floating support structures on the drivetrain dynamic responses and the influence of drivetrain layout and design choices on the support structure were considered and presented. In recent years, there has been a trend towards compacting and inverting drivetrain designs, resulting in different weight and mass distribution on the tower top. The choice of the generator technology were also

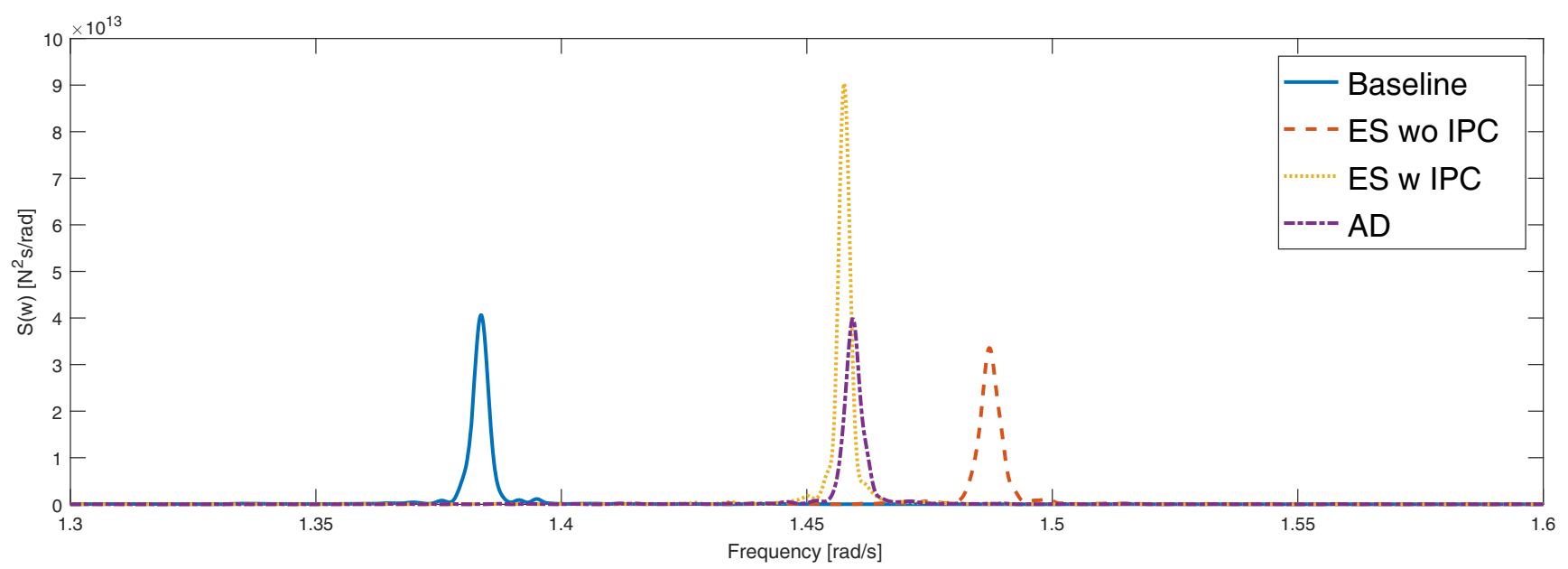

Fig. 7 Radial force on main bearing, at rated wind speed [6] 
Fig. 8 Performance comparison. 1-hour fatigue damage at the tower base $\left(\chi_{D_{\text {TowerBase }}}\right)$, 1-hour fatigue damage at main bearing $\left(\chi_{D_{\text {bearing }}}\right), 1$-hour fatigue damage at first stage sun gear $\left(\chi_{D_{\text {gear }}}\right)$, and power standard deviation $\left(\chi_{\sigma_{\text {power }}}\right)[6]$. a

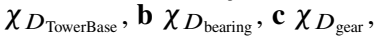
d $\chi_{\sigma_{\text {power }}}$

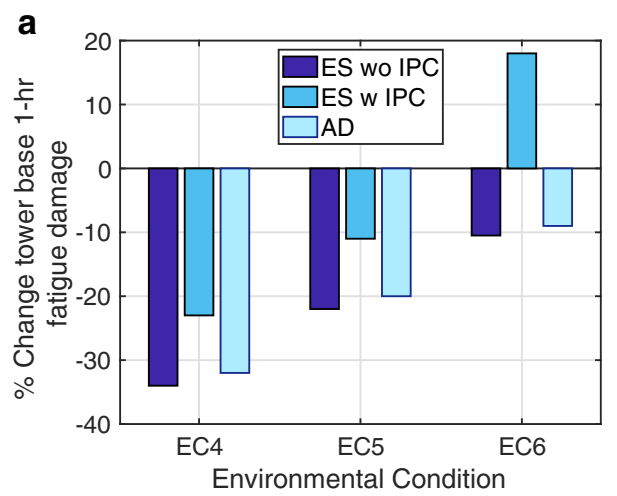

$\chi D_{\text {TowerBase }}$

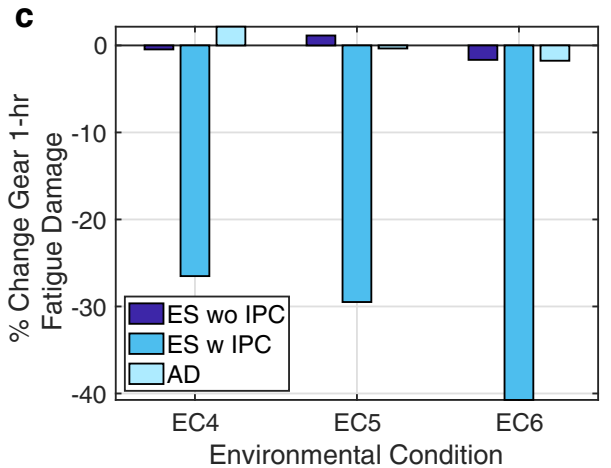

$\chi_{\text {gear }}$ b

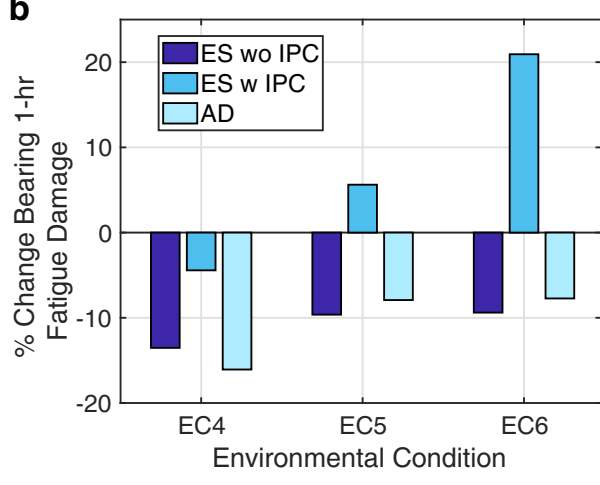

$\chi D_{\text {bearing }}$

d

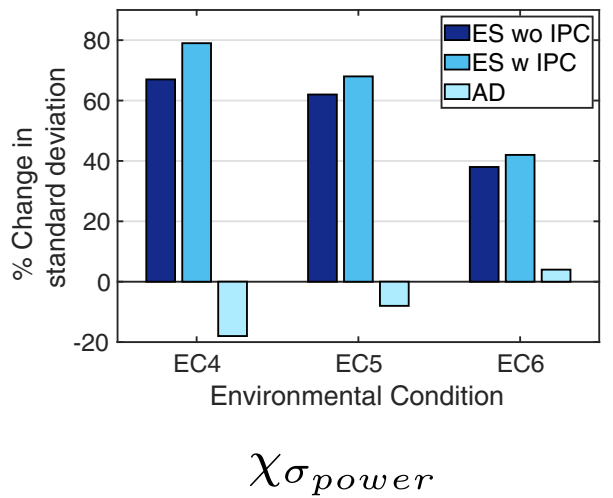

discussed, again in terms of weight, but also considering the operational and maintenance cost in a life cycle perspective.

From the drivetrain design point of view, with respect to the influence of a floating support structure, the aspects of floater motion, maximum axial acceleration on the tower top, bedplate flexibility and impact of control were discussed. The lessons learned from these studies indicate that the effect of floater motion on drivetrain responses are likely overshadowed by the wind induced load effects, especially for larger turbines. It was also highlighted that the tower top axial acceleration may also not be a reasonable indicator for the drivetrain components' life. In terms of modeling and control, the results emphasized the importance of understanding the coupling effects between the support structure and the drivetrain, especially for compact and inverted designs.

The industry has not yet matured with respect to the drivetrain type and configuration, even for bottom-fixed turbines, and more research efforts are certainly needed for floating and larger turbines, considering the limited experience. The aim of this paper was mainly to share the results of the last ten years of own research on this subject. Because of the diversity of drivetrain designs, it should be noted that there are limitations in the universal validity of the results presented, and that one should not generalize the results for other types and configurations without a thorough study and investigation.

\section{Conflict of interest}

The authors declare that they have no conflict of interest.

Acknowledgements Results presented in this article are outcomes of collaboration over the last ten years with colleagues and doctoral candidates at Marine Technology Department and Marine System Dynamics and Vibration Lab (MD Lab) at NTNU which is greatly appreciated. This work was also partially supported by Equinor ASA, and the Research Council of Norway through project number 263819.

Funding Open access funding provided by NTNU Norwegian University of Science and Technology (incl St. Olavs Hospital - Trondheim University Hospital)

Open Access This article is licensed under a Creative Commons Attribution 4.0 International License, which permits use, sharing, adaptation, distribution and reproduction in any medium or format, as long as you give appropriate credit to the original author(s) and the source, provide a link to the Creative Commons licence, and indicate if changes 
were made. The images or other third party material in this article are included in the article's Creative Commons licence, unless indicated otherwise in a credit line to the material. If material is not included in the article's Creative Commons licence and your intended use is not permitted by statutory regulation or exceeds the permitted use, you will need to obtain permission directly from the copyright holder. To view a copy of this licence, visit http://creativecommons.org/licenses/by/4. $0 /$.

\section{References}

1. van Binsbergen DW, Wang S, Nejad AR (2020) Effects of induction and wake steering control on power and drivetrain responses for 10 MW floating wind turbines in a wind farm. J Phys Conf Ser 1618:22044

2. Chen G, Wen J (2012) Load performance of large-scale rolling bearings with supporting structure in wind turbines. J Tribol. https://doi.org/10.1115/1.4007349

3. Jassal Ir A, Versteegh K, Polinder H (2013) Case study of the permanent magnet direct drive generator in the Zephyros wind turbine. In: Electrical drives for direct drive renewable energy systems. Elsevier, Cambridge, pp 158-174

4. Jonkman J, Butterfield S, Musial W, Scott G (2009) Definition of a 5-MW reference wind turbine for offshore system development. Tech. rep.. National Renewable Energy Lab (NREL), Golden

5. Jonkman JM, Annoni J, Hayman G, Jonkman B, Purkayastha A (2017) Development of FAST.Farm: a new multiphysics engineering tool for wind farm design and analysis. Tech. rep.. NREL, Golden

6. Lee CF, Bachynski EE, Nejad AR (2020) Consequences of load mitigation control strategies for a floating wind turbine. J Phys Conf Ser 1669:12014

7. Moghadam FK, Nejad AR (2020) Evaluation of PMSG-based drivetrain technologies for 10-MW floating offshore wind turbines: pros and cons in a life cycle perspective. Wind Energy 23(7):1542-1563

8. Nejad AR, Bachynski EE, Gao Z, Moan T (2015) Fatigue damage comparison of mechanical components in a land-based and a spar floating wind turbine. Proc Eng 101:330-338
9. Nejad AR, Bachynski EE, Kvittem MI, Luan C, Gao Z, Moan T (2015) Stochastic dynamic load effect and fatigue damage analysis of drivetrains in land-based and TLP, spar and semi-submersible floating wind turbines. Mar Struct 42:137-153

10. Nejad AR, Bachynski EE, Moan T (2019) Effect of axial acceleration on drivetrain responses in a spar-type floating wind turbine. J Offshore Mech Arct Eng. https://doi.org/10.1115/1.4041996

11. Nejad AR, Guo Y, Gao Z, Moan T (2016) Development of a 5 MW reference gearbox for offshore wind turbines. Wind Energy 19(6):1089-1106

12. Plaza J, Abasolo M, Coria I, Aguirrebeitia J, de Bustos IF (2015) A new finite element approach for the analysis of slewing bearings in wind turbine generators using superelement techniques. Meccanica 50(6):1623-1633

13. Torsvik J (2020) Dynamic analysis in design and operation of large floating offshore wind turbine drivetrains. Doctoral theses at Norwegian University of Science and Technology, Marine Technology Department; 2020 :403. https://hdl.handle.net/11250/2719036

14. Torsvik J, Nejad AR, Pedersen E (2018) Main bearings in large offshore wind turbines: development trends, design and analysis requirements. J Phys Conf Ser 1037:42020

15. Torsvik J, Nejad AR, Pedersen E (2021) Experimental study of floater motion effects on a main bearing in a spar floating wind turbine. Mar Struct : (Under review)

16. Versteegh CJA (2004) Design of a direct drive PM generator for application in the Zephyros Z72 Sind turbine. In: NORPIE 2004, p 68

17. Wang S, Nejad AR, Bachynski EE, Moan T (2020) Effects of bedplate flexibility on drivetrain dynamics: case study of a $10 \mathrm{MW}$ spar type floating wind turbine. Renew Energy 161:808-824

18. Wang S, Nejad AR, Moan T (2020) On design, modelling, and analysis of a 10-MW medium-speed drivetrain for offshore wind turbines. Wind Energy 23(4):1099-1117

19. Xing Y, Karimirad M, Moan T (2012) Effect of spar-type floating wind turbine nacelle motion on drivetrain dynamics. In: Proceedings of EWEA 2012 annual event 